\title{
ISOLATION AND CHARACTERIZATION OF ANTIOXIDANT COMPOUNDS OF BANGUN-BANGUN (Coleus amboinicus, L.) LEAVES FROM NORTH SUMATERA, INDONESIA
}

\author{
K. Gurning ${ }^{1, \bigotimes}$, W. Haryadi ${ }^{2}$ and H. Sastrohamidjojo ${ }^{2}$ \\ ${ }^{1}$ Department of Pharmacy, Sekolah Tinggi Ilmu Kesehatan Senior Medan, \\ Medan-20141, Indonesia \\ 2 Department of Chemistry, Faculty of Mathematics and Natural Science, Universitas Gadjah \\ Mada, Yogyakarya-55281, Indonesia \\ ${ }^{\bowtie}$ Corresponding Author: kastagurning@gmail.com
}

\begin{abstract}
Coleus amboinicus, Lour has been successfully isolated and characterized active isolates from the ethyl acetate fraction and tested its antioxidant activity. Isolation was carried out by maceration method with methanol followed by stratified fractionation with $n$-hexane, chlorofrom and ethyl acetate. The each fraction was tested for antioxidant potential by DPPH method at a wavelength of $515 \mathrm{~nm}$ and the ethyl acetate fraction gave a better antioxidant potential then it's purified. Purification using by gravitational column chromatography with the stationary phase silica gel 60 and the mobile phase ratio of $n$-hexane: ethyl acetate with polarity are gradually increased. Isolates were characterized by UV, FT-IR, NMR, and GC-MS spectrophotometry. Antioxidant activity $\left(\mathrm{IC}_{50}\right.$ ) test obtained 386.46. The molecular formula is $\mathrm{C}_{22} \mathrm{H}_{28} \mathrm{O}_{6}$ isolate with the name of the chemical compound 16-hydroxy-7 $\alpha$-acetoxyroyleanone (syn. 16-hydroxy-7-O-acetylhorminone).
\end{abstract}

Keywords: Antioxidant, Coleus amboinicus, DPPH, Ethyl acetate, Stratified fractionation

RASĀYAN J. Chem., Vol. 14, No.1, 2021

\section{INTRODUCTION}

The potential of plants in recent times is become the center of attention of researchers in a variety of uses. This is because in addition to the nutritional content, this plants also have secondary metabolites (bioactive compounds) that is potential to be developed for various of natural treatments. ${ }^{1,2,3}$ One of the plants that can be utilized is bangun - bangun (the name of the Bataknese area, North Sumatera Province, Indonesia). The bangun -bangun plant with the latin name is Coleus amboinicus, L., with the synonym Plectranthus amboinicus (Lour) Spreng., and Coleus aromaticus, Benth., ${ }^{4,5,6}$ Traditionally, people in north Sumatera Indonesia consumes leaves as vegetables and believed it's able to increase the productivity of breast milk when breastfeeding. ${ }^{7}$

The leaves of C.amboinicus is reported contain alkaloids, carbohydrates, glycosides, proteins, flavonoids, tannins, phenolics and terpenoids ${ }^{8}$ and has essential oils. ${ }^{9}$ C.amboinicus has potential as an antioxidant, diuretic, analgesic, prevent cancer, antitumor, antivertigo, immunostimulant, antiinflammatory, anti-infertilization, hypocholesterolemic, hypotensive. ${ }^{7}$ The various of degenerative diseases that arise are very closely related to the presence of free radicals. Free radicals is the most reactive species. The presence of free radicals can be minimized by the effects of antioxidant compounds. C.amboinicus can be used as a potential herbal medicine which is active as a natural antioxidant. Antioxidants that are natural are considered safer than synthetic antioxidants. Based on the description, the purpose of this research was to isolate potential compounds from C. amboinicus leaves fraction as an antioxidants.

\section{EXPERIMENITAL}

\section{Chemicals}

The chemicals used were methanol pa, $n$-hexane pa, pa ethylacetate, chloroform (Merck), acetone (Merck), $\mathrm{NH} 4 \mathrm{OH}$ (Merck), NaOH (Merck), dragendorff (Merck), anhydrous acetic acid (Merck), ethanol (Merck) ), FeCl3 (Merck), $\mathrm{Mg}$ powder (Merck), $\mathrm{HCl}$ (pa), $\mathrm{KOH}$ (Merck), sulfuric acid (Merck), GF256 silica gel TLC plate (Merck), silica gel 60 (kieselgel 0.063-0.0200 mm) (Merck), aquabides and DPPH (Merck). Instrumentation used UV-Vis spectrometers (spectronic 3000, Genesis 
10), FT-IRKBr spectrophotometry (Shimadzu IR Prestige-21), NMR spectrometers (JEOL spectrometers), GC-MS-QP2010S Shimadzu and Electrothermal 9100.

\section{Preparation and Process of the Extract Plant}

The C. amboinicus was originated from the village of Sosor Ladang, sub-district Parmaksian, North Sumatera Province, Indonesia and this plant identification is carried out at the botanist at the Faculty of Biology, Universitas Gadjah Mada, Indonesia (No.0437/S.Tb/V/2013). The C. amboinicus was cleaned by the running water and then dried in an open room (avoid direct contact with sunlight). The sample was mashed with an electric blender and obtained a weight of 950 g. C. amboinicus powder was extracted by maceration with methanol for 48 hours, then filtered and concentrated with a rotary vacuum evavorator at $50^{\circ} \mathrm{C}$. The residue was reminerated and repeated two times. The crude extract of methanol obtained is partitioned in stages starting with $n$-hexane, chloroform and ethyl acetate solvents with two replications each. Clarifying the boundary plane at the time of fractionation is done to add sufficient distilled water. The ethyl acetate fraction resulting from the partition is continue to the purification stage.

\section{Antioxidant Activity Test}

The Each extraction and fraction is tested for antioxidant activity by using DPPH method (2,2diphenyl-1-picrylhydrazyl) with varying concentrations of of $50 \mathrm{ppm}, 75 \mathrm{ppm}, 100 \mathrm{ppm}, 125 \mathrm{ppm}$ and $150 \mathrm{ppm} .250 \mu \mathrm{L}$ of each concentration and $1 \mathrm{~mL}$ DPPH $0.4 \mathrm{mM}$ then added exactly $5 \mathrm{~mL}$ methanol, then incubated for 30 minutes in a closed state. Blank (negative control) $1 \mathrm{~mL}$ DPPH $0.4 \mathrm{mM}$ added 4 $\mathrm{mL}$ methanol without extract and incubated for 30 minutes. $^{10}$ Absorbance was measured at a wavelength of $515 \mathrm{~nm}$ with a visible spectrophotometer. ${ }^{11,12}$ Determination of free radical inhibition with the following equation:

$$
\text { Percentage Inhibition }=\left[\frac{A_{0}-A_{T}}{A_{n}}\right] \times 100
$$

Where, $\mathrm{A}_{0}=$ Absorbance blank and $\mathrm{A}_{\mathrm{T}}=$ Absorbance of the test sample. $\%$ inhibition is plotted against concentration and get a regression equation linear is obtained to calculate the inhibitory concentration $\left(\mathrm{IC}_{50}\right) . \mathrm{IC}_{50}$ is expressed as the amount of an antioxidant extract that reacts with an initial DPPH radical of $50 \% .^{13,14}$

\section{Purification}

The purification by using silica gel 60 as a stationary phase by gravity column chromatography. The gravity column used was $1 \mathrm{~cm}$ in diameter with $40 \mathrm{~cm}$ in height. $2 \mathrm{~g}$ of ethyl acetate fraction is mixed evenly with $0.5 \mathrm{~g}$ of silica gel. The column were filled with $3 \mathrm{~g}$ silica gel and compacted with $\mathrm{n}$ hexane. Purification by using the mobile phase between n-hexane: ethyl acetate and polarity are increased gradually. The selection of eluents as mobile phases is based on identifying the better separation in thin layer chromatography (TLC) under ultraviolet light and visible light at wavelengths $(\lambda)$ of $254 \mathrm{~nm}$ and $366 \mathrm{~nm}$. The eluate was collected in vial of bottles with each a volume of $10 \mathrm{~mL}$ and then evaporate. The isolates were analyzed by using UV-Vis, FT-IR, ${ }^{1} \mathrm{H} \&{ }^{13} \mathrm{C}-\mathrm{NMR}, \mathrm{GC}-\mathrm{MS}$ spectrophotometry and tested as antioxidant activity.

\section{Sample Preparation}

\section{RESULTS AND DISCUSSION}

Weight percentages of each extract and fraction leaves of $C$. amboinicus powder and crew antioxidant activity were presented in Table-1.

Table-1:The Percentage of Extract and Fraction of Weight of Powder and $\mathrm{IC}_{50}$ from C. amboinicus Leaves

\begin{tabular}{c|c|c|c|c|c} 
& $\begin{array}{c}\text { Crude Methanol } \\
\text { Extract }\end{array}$ & $\begin{array}{c}\text { Fraction } \\
\text { n-hexane }\end{array}$ & $\begin{array}{c}\text { Fraction } \\
\mathrm{CHCl3}\end{array}$ & $\begin{array}{c}\text { Fraction } \\
\text { EtOAc }\end{array}$ & $\begin{array}{c}\text { Fraction } \\
\text { Residue }\end{array}$ \\
\hline Powder & $58.44 \mathrm{~g}$ & $25.63 \mathrm{~g}$ & $20.94 \mathrm{~g}$ & $4.43 \mathrm{~g}$ & $7.45 \mathrm{~g}$ \\
$(950.0 \mathrm{~g})$ & $(6.13 \%)$ & $(2.69 \%)$ & $(2.20 \%)$ & $(0.47 \%)$ & $(0.78 \%)$ \\
\hline IC $_{50}$ & $34.73 \pm 0.10^{*}$ & - & $167.06 \pm 1.10^{*}$ & $65.85 \pm 0.75^{* \mathrm{a}}$ & - \\
Early & & & & & \\
\hline
\end{tabular}

Description: * The results are expressed as mean $\pm \mathrm{SD}, \mathrm{n}=3$ and ${ }^{* a}$ purified fraction 


\section{Isolate from the Purification of Ethyl Acetate Faction}

The eluate was collected and in vial bottle number 5 a crystal was obtained in the eluent $n$-hexane (10): ethyl acetate (1) ratio. The crystals (isolates) obtained weighing $50 \mathrm{mg}(1.13 \%)$ were yellow, vase-shaped, and tapered (Fig.-1).

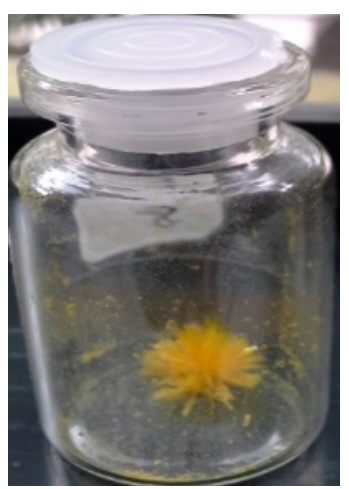

Fig.-1: Isolate

\section{Characterization and Analysis of Isolate Structures}

The characterization of isolates by measuring melting points $214-215^{\circ} \mathrm{C}$. The isolate was completely dissolved with methanol, ethyl acetate, and chloroform. Characterization using various instruments was presented in Table- 2 .

Table-2: Characterization of Isolates with Various Instruments

\begin{tabular}{|c|c|c|c|c|c|c|}
\hline \multicolumn{2}{|c|}{ UV spectrophotometry } & \multicolumn{2}{|c|}{ FT-IR $(\mathrm{KBr})$} & \multicolumn{3}{|c|}{ GC-MS } \\
\hline $\begin{array}{l}\text { Uptake } \lambda \\
\text { (nm) }\end{array}$ & Absorbansi & $\begin{array}{l}\text { Wave Number } \\
\qquad\left(\mathrm{cm}^{-1}\right)\end{array}$ & $\begin{array}{l}\text { Interpretation of } \\
\text { functional groups }\end{array}$ & $\begin{array}{c}\text { Retention } \\
\text { time } / t_{R} \\
\text { (minutes) }\end{array}$ & $\%$ Area & $\begin{array}{l}\mathrm{MS} \\
(\mathrm{m} / \mathrm{z})\end{array}$ \\
\hline 210 & Methanol (Solvent) & 3425 and 3387 & $-\mathrm{OH}$ & \multirow[t]{5}{*}{7.316} & \multirow[t]{5}{*}{100} & \multirow[t]{5}{*}{390} \\
\hline \multirow[t]{4}{*}{274} & \multirow[t]{4}{*}{ Isolated } & 2394 & C-H aliphatic & & & \\
\hline & & 1728 & $\mathrm{C}=\mathrm{O}$ esters & & & \\
\hline & & 1234 & C-O methoxy & & & \\
\hline & & 1643 & $\mathrm{C}=\mathrm{C}$ alkenes & & & \\
\hline
\end{tabular}

The results of the proton analysis with 1H-NMR obtained 28 types of protons and carbon analysis with 13C-NMR there were 22 types of carbon. Structural analysis followed by 2D-NMR (HMBC) was shown in Table-3. Molecular structure of the results of NMR spectra analysis was shown in Fig.2 .<smiles>CC(=O)O[C@H]1CC2C(C)(C)CCC[C@]2(C)C2=C1C(=O)C(C(C)CO)=C(O)C2=O</smiles>

Fig.-2: Molecular Structure of Isolates (16-hydroxy-7 $\alpha$-acetoxyroyleanone syn. 16-hydroxy-7-Oacetylhorminone)

The GC-MS analysis results showed a molecular weight of $390 \mathrm{~m} / \mathrm{z}$, prediction of the fragmentation pattern of the isolate with the molecular formula of $\mathrm{C}_{22} \mathrm{H}_{28} \mathrm{O}_{6}$ isolate with the name of the chemical compound 16-hydroxy-7 $\alpha$-acetoxyroyleanone (Fig.-3).

\section{Isolate (16-hydroxy-7a-acetoxyroyleanone) Antioxidant Activity Test}

The analysis antioxidant activity of the isolates was carried out by using the DPPH method. This method uses a measurement process that is easy, fast and has a good level of sensitivity to the determination of antioxidant activity. Increasing the concentration of isolates showed an increase in percent reduction of free radicals from $\mathrm{DPPH}$. The percentage inhibition of free radicals and $\mathrm{IC}_{50}$ activity of the isolate was shown in Fig.-4. 
a.

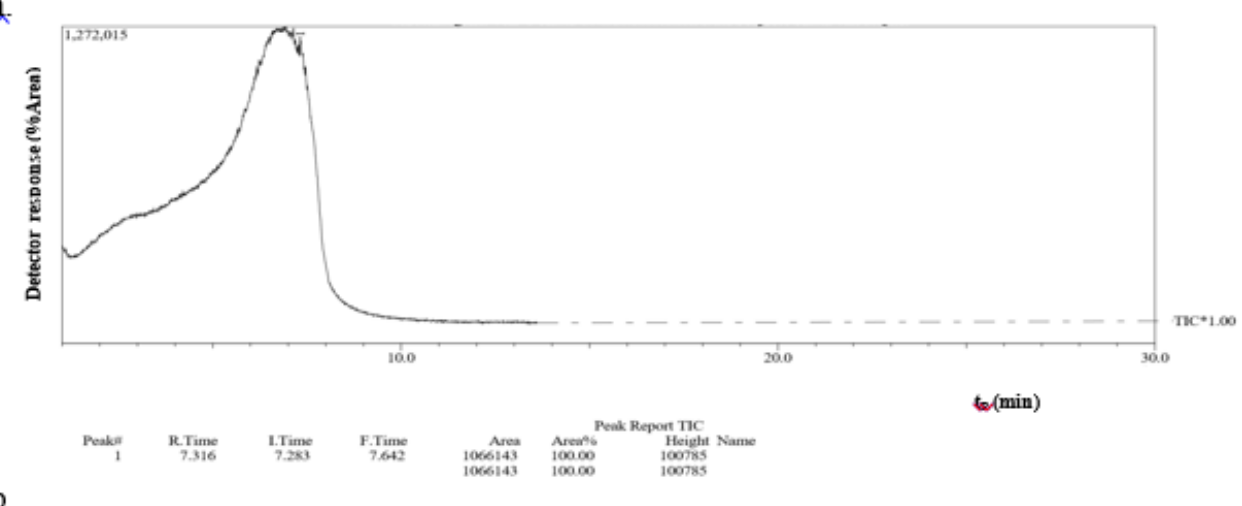

b.

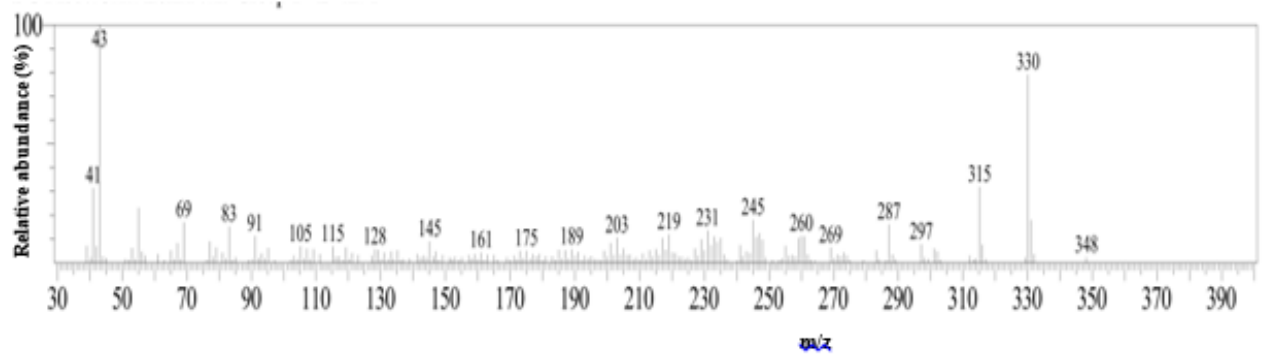

\&.

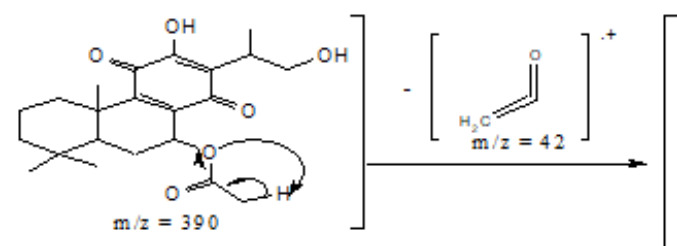<smiles>CC=COCC</smiles>

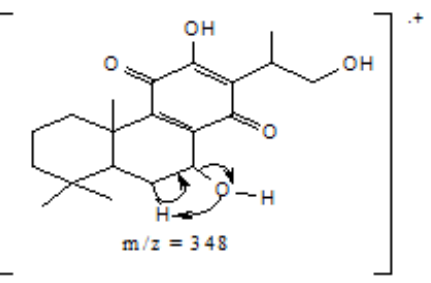

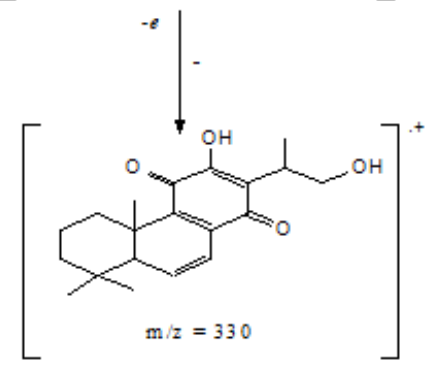

Fig.-3: (a) Chromatogram on GC, (b)MS Spectrum and (c) Fragmentation Pattern of 16-hydroxy-7 $\alpha$ acetoxyroyleanone Structure

Table-3: Chemical Shifts and HMBC Isolates

\begin{tabular}{c|c|l|l}
\hline $\begin{array}{c}\text { Carbon } \\
\text { Position }\end{array}$ & $\delta_{\mathrm{C}}(\mathrm{ppm})$ & \multicolumn{1}{|c}{$\delta_{\mathrm{H}}(\mathrm{ppm})$} & HMBC \\
\hline 1 & 38,54 & $2,62-2,66 t t,\left(2 \mathrm{H},{ }^{3} J_{C H} 5,2 \mathrm{~Hz} ; 4,6 \mathrm{~Hz}\right)$ & $2,3,10,9,5,20$ \\
\hline 2 & 24,36 & $1,47-1,50 t t,\left(2 \mathrm{H},{ }^{3} J_{C H} 5,2 \mathrm{~Hz} ; 4,6 \mathrm{~Hz}\right)$ & $1,3,19,5$ \\
\hline 3 & 42,45 & $1,57 t(2 \mathrm{H}, J=3,85 \mathrm{~Hz})$ & $4,18,2,19$ \\
\hline 4 & 33,86 & & \\
\hline 5 & 49,93 & $1,83-1,87 t t\left(1 \mathrm{H},{ }^{3} J_{C H} 5,2 \mathrm{~Hz} ; 4,6 \mathrm{~Hz}\right)$ & $1,6,2,10,9$ \\
\hline 6 & 21,69 & $1,78 s(2 \mathrm{H}$, melebar $)$ & $5,8,7,10,9$ \\
\hline 7 & 68,93 & $5,66 d(1 \mathrm{H})$ & $5,8,9,1,14$ \\
\hline 8 & 137,27 & & \\
\hline 9 & 150,09 & & \\
\hline 10 & 38,81 & & \\
\hline 11 & 183,47 & & \\
\hline
\end{tabular}


RASĀYAN J. Chem.

Vol. 14 | No. 1 |248-253| January - March | 2021

\begin{tabular}{c|l|l|l}
\hline 12 & 151,08 & & \\
\hline 13 & 124,86 & & \\
\hline 14 & 185,94 & & $16,17,13,12,14$ \\
\hline 15 & 20,03 & $3,17 \mathrm{~m}(1 \mathrm{H})$ & $15,17,13$ \\
\hline 16 & 67,24 & $4,32 \mathrm{~s}($ widened $)(2 \mathrm{H})$ & $16,15,13$ \\
\hline 17 & 19,15 & $1,20 \mathrm{~d},(3 \mathrm{H}, \mathrm{J}=12,03 \mathrm{~Hz})$ & $3,4,5,19$ \\
\hline 18 & 33,72 & $1,24 \mathrm{~d},(6 \mathrm{H}, \mathrm{J}=5 \mathrm{~Hz})$ & $2,3,4,5,18$ \\
\hline 19 & 24,01 & & $10,1,5,9$ \\
\hline 20 & 19,90 & $0,94 \mathrm{~s}(3 \mathrm{H})$ & 1 \\
\hline $1{ }^{\prime}$ & 169,77 & & $11,12,13$ \\
\hline 2 & 21,13 & $2,05 \mathrm{~s}(3 \mathrm{H})$ & \\
\hline $\begin{array}{c}\text { at }-\mathrm{OH} \\
\mathrm{C}-12\end{array}$ & & $7,21 \mathrm{~s}$ brs & \\
at $-\mathrm{OH}$ & & & \\
$\mathrm{C}-16$ & & & \\
\hline
\end{tabular}

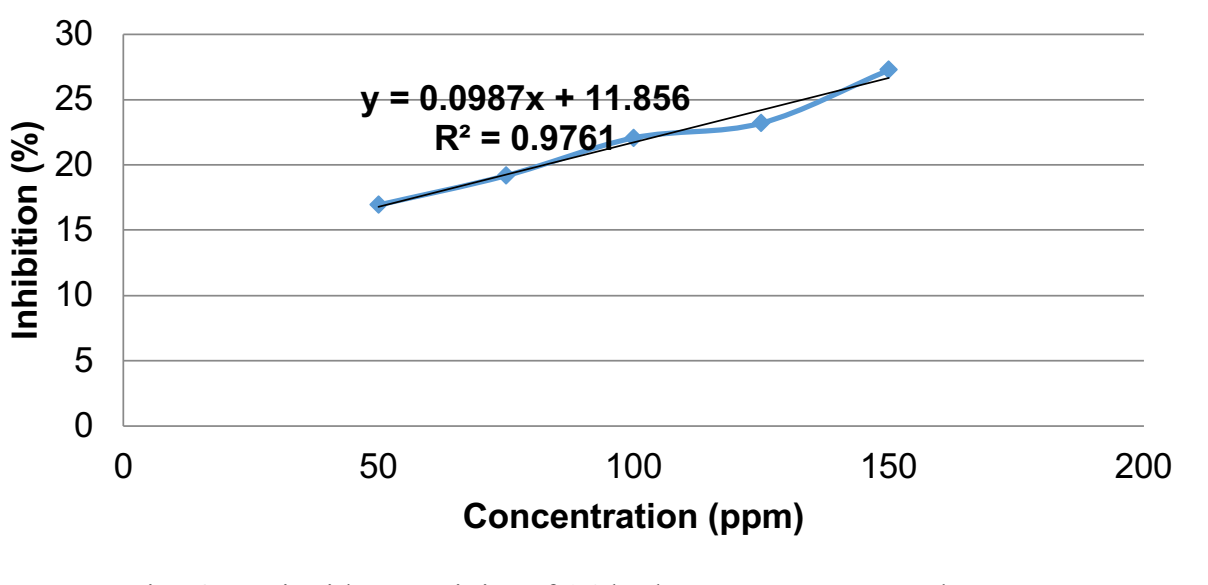

Fig.-4: Antioxidant Activity of 16-hydroxy-7 $\alpha$-acetoxyroyleanone

The antioxidant activity was expressed by the ability of isolates to reduce $50 \%$ of free radicals sourced from DPPH. The value of antioxidant activity $\left(\mathrm{IC}_{50}\right)$ of isolates was 386.46 . The principle of reducing free radicals from DPPH by involving proton and electron transperts from isolates to free radicals to form a neutral DPPH-H compound that is not reactive. ${ }^{15}$

\section{CONCLUSION}

The C. amboinicus leaf extraction with various methanol, chlorofrom and ethyl acetate solvents showed antioxidant activity which was tested by DPPH method. Isolate isolated from ethyl acetate fraction showed $\mathrm{IC}_{50} 386.46$ which had weaker activity than the extract. The molecular formula is $\mathrm{C}_{22} \mathrm{H}_{28} \mathrm{O}_{6}$ isolate with the name of the chemical compound 16-hydroxy-7 $\alpha$-acetoxyroyleanone (syn. 16-hydroxy-7-O-acetylhorminone).

\section{ACKNOWLEDMENT}

Thank you to the Lembaga Pengelolah Dana Pendidikan (LPDP) Indonesia for funding my research in 2014.

\section{REFERENCES}

1. Q.D. Do, A.E. Angkawijaya, P. Tran-Nguyen, L.H. Hunynh, F.E. Soetaredjo, S. Ismadji and Y.H. Ju. Journal of Food and Drug Analysis, 22(3), 1(2014), DOI:10.1016/j.jfda.2013.11.001

2. J.T. Lin, S.C. Liu, L.C. Kuo and D.Y. Yang. Journal of Food and Drug Analysis, 26(1), 193(2018), DOI:10.1016/j.jfda.2017.03.004

3. Y.H. Lee, B. Kim, S. Kim, M.S. Kim, H. Kim, S.R. Hwang, K. Kim and J.H. Lee. J Journal of Food and Drug Analysis, 25(4), 776(2017), DOI:10.1016/j.jfda.2016.09.003

4. S. Thilagavathi and N. Nariram. International Journal of Science and Research Methodology, 4(4), 18(2016).

5. K. Girish. Journal of Pharmacy Research, 10(10), 635(2016). 
6. D.D. Wadikar and P.E. Patki. Journal of Food Science and Technology, 53(7), 2895(2016), DOI:10.1007/s13197-016-2292-y

7. R. Rosidah and P.A.Z. Hasibuan. International Journal of PharmTech Research, 6(6), 1806(2014).

8. G. Arumugam, M.K. Swamy and U.R. Sinniah. Molecules, 21(4), 369(2016), DOI: $10.3390 /$ molecules 21040369

9. P. Selvakumar, B. Naveena and S.D. Prakash. Asian Pacific Journal of Tropical Disease, 2(2), S715(2012), DOI:10.1016/S2222-1808(12)60250-3

10. O.T. Wahyuni and T. Hertiani. Traditional Medicine Journal, 21(2), 86(2016), DOI: $10.22146 /$ tradmedj. 12822

11. M. Simorangkir, W. Hutabarat, B. Nainggolan and S. Silaban. Rasāyan Journal of Chemistry, 12(2), 959(2019), DOI:10.31788/RJC.2019.1225095

12. R. Hardiyanti, L. Marpaung, I.K. Adnyana and P. Simanjuntak. Rasāyan Journal of Chemistry, 12(4), 1822(2019), DOI:10.31788/RJC.2019.1235353

13. W.D. Fitriana, T. Ersam, K. Shimizu and S. Fatmawati. Indonesian Journal of Chemistry, 16(3), 297(2016), DOI:10.22146/ijc.21145

14. R. El-Haskoury, W. Kriaa, B. Lyoussi and M. Makni. Journal of Food and Drug Analysis, 26(1), 67(2018), DOI:10.1016/j.jfda.2016.11.016

15. A. Maimulyanti, A.R. Prihadi and I. Safrudin. Indonesian Journal of Chemistry, 2(16), 162(2016), DOI:10.22146/ijc. 21160

[RJC-6077/2020] 